\title{
Soil conditioning index and soil organic carbon in the Midwest and southeastern United States
}

\section{A.J. Franzluebbers, H.J. Causarano, and M.L. Norfleet}

\begin{abstract}
Calibration of the soil conditioning index (SCI) to a diversity of field studies with known changes in soil organic carbon (SOC) would improve the usefulness of the SCI by the USDA Natural Resources Conservation Service to assess the environmental services provided by agricultural land stewardship. Our objectives were to (1) calibrate SCI scores against SOC from published field studies in the Midwest and (2) compare the calibration with a recently derived calibration from the southeastern United States. We found that SOC sequestration (at $25 \pm 6 \mathrm{~cm}$ [10 $\pm 2 \mathrm{in}] \mathrm{depth}$ ) could be reliably related to SCI across a diversity of studies in the region using the regression slope: $4.52 \mathrm{Mg} \mathrm{C} \mathrm{ha}^{-1} \mathrm{SCI}^{-1}\left(2.02 \mathrm{tn} \mathrm{ac}^{-1} \mathrm{SCI}^{-1}\right)$, which translated into a rate of $0.35 \pm 0.06 \mathrm{Mg} \mathrm{C} \mathrm{ha}^{-1} \mathrm{y}^{-1} \mathrm{SCI}^{-1}\left(314 \pm 57 \mathrm{lb} \mathrm{ac}^{-1} \mathrm{yr}^{-1} \mathrm{SCI}^{-1}\right)$, which is the mean \pm standard error of 18 slope estimates. Calibration slopes did not vary significantly between the Midwest and southeastern United States, resulting in a combined calibration of $0.29 \pm 0.03 \mathrm{Mg} \mathrm{Cha}^{-1} \mathrm{y}^{-1} \mathrm{SCI}^{-1}\left(255 \pm 30 \mathrm{lb} \mathrm{ac}^{-1} \mathrm{yr}^{-1} \mathrm{SCI}^{-1}\right)$, which is the mean \pm standard error of 49 slope estimates. The calibration of SCI scores to SOC will allow SCI to become a quantitative tool for natural resource professionals to predict SOC sequestration for farmers wanting to adopt conservation practices.
\end{abstract}

Key words: conservation tillage—crop rotation—modeling-no-tillage- organic matter

\begin{abstract}
Rapid and reliable assessments of the potential of different agricultural management systems to sequester soil organic carbon (SOC) are needed to promote conservation and help mitigate greenhouse gas emissions. Several recent regional literature reviews have documented the potential of conservation agricultural systems to sequester SOC (West and Post 2002; VandenBygaart et al. 2003; Franzluebbers 2005; 2010; Johnson et al. 2005; Liebig et al. 2005). Unfortunately, results appear to be site, soil, and cropping system specific, resulting in uncertainty of how to predict the effect of management in different environments (Varvel 1994; Dick et al. 1998; VandenBygaart et al. 2002; Venterea et al. 2006; Gál et al. 2007).
\end{abstract}

The soil conditioning index (SCI) is a relatively simple model to parameterize and is currently used by the USDA Natural Resources Conservation Service to predict relative changes in SOC. However, it is currently only used as a nonquantitative tool to summarized across various landscape features, farm units, and time periods.

When evaluated on farm fields of the Southern High Plains in Texas, SCI was significantly related (but only weakly) to differences in SOC as a result of different land uses (e.g., inversion versus no-tillage, dryland versus irrigated, cropping versus grassland) (Zobeck et al. 2007). On a multiple-year experiment in Colorado, SCI from five different irrigated cropping systems under conventional and no-tillage was highly related to SOC (Zobeck et al. 2008). From the Solutions to Environmental and Economic Problems (STEEP) project in the Pacific Northwest, SCI values gradually increased from strongly negative values in 1975 to neutral to positive values in 2005 with progressive adoption of improved conservation technology and farming systems (Kok et al. 2009). At three locations in the southeastern United States, SCI and the Environmental Policy Integrated Climate (EPIC) model were effective at differentiating potential SOC changes with adoption of increasingly diversified rotations with cotton (Gossypium hirsutum L.) under no-tillage against monoculture cotton under conventional tillage (Abrahamson et al. 2007). All of these studies indicate that SCI should be related to changes in SOC with adoption of conservation compared with conventional management, but quantitative relationships with actual field data are scant.

Recently, calibration of SCI against SOC content was determined for a diversity of field studies in the southeastern United States (Franzluebbers et al. 2010). From a total of 31 studies in the region, each unit change in SCI was calibrated to a SOC sequestration rate of $0.25 \pm 0.04 \mathrm{Mg}$ carbon $(\mathrm{C}) \mathrm{ha}^{-1} \mathrm{y}^{-1}(220 \pm 34$ $\left.\mathrm{lb} \mathrm{ac}^{-1} \mathrm{yr}^{-1}\right)$. There was concern raised that the calibration in the southeastern United States might be different than other regions due to the widespread use of low-residue producing cotton and highly disturbed condition with peanut (Arachis hypogaea L.) harvesting, even with conservation management. Therefore, the eastern United States. Unfortunately, SOC was evaluated only on a concentration basis ( $\left.\mathrm{mg} \mathrm{g}^{-1}[\%]\right)$ and not on an area basis $\left(\mathrm{Mg} \mathrm{ha}^{-1}\left[\mathrm{tn} \mathrm{ac}^{-1}\right]\right)$ due to lack of information on bulk density. Changes in SOC will likely be most meaningful to the diversity of parties interested in its change (e.g., scientists, brokers, and policy makers) when reported as $\mathrm{Mg}$ $\mathrm{ha}^{-1} \mathrm{y}^{-1}\left(\mathrm{tn} \mathrm{ac}^{-1} \mathrm{yr}^{-1}\right)$ so that estimates can be
Alan J. Franzluebbers is an ecologist at the USDA Agricultural Research Service in Watkinsville, Georgia. Hector J. Causarano is a soil scientist at the National University of Asuncion, San Lorenzo, Paraguay. M. Lee Norfleet is a soil scientist at the Blackland Research and Extension Center in Temple, Texas. 


\section{Table 1}

Locations and conditions for comparing soil organic carbon and soil conditioning index in the Midwest United States.

\begin{tabular}{|c|c|c|c|c|}
\hline $\begin{array}{l}\text { Experiment } \\
\text { Number }\end{array}$ & $\begin{array}{l}\text { Location } \\
\text { (state/county) }\end{array}$ & Soil & $\begin{array}{l}\text { Management } \\
\text { variables }\end{array}$ & Source \\
\hline 1 & lowa/Chickasaw & Floyd L & Tillage & Karlen et al. (1998) \\
\hline 3 & Illinois/Dekalb & Drummer SiCL & Tillage & Wander et al. (1998) \\
\hline 4 & Illinois/Pike & Ipava SiL & Tillage & Wander et al. (1998) \\
\hline 5 & Illinois/Warren & Muscatune SiL & Tillage & Wander et al. (1998) \\
\hline 7 & Indiana/Tippecanoe & Chalmers SiCL & Tillage, rotation & Elliott et al. (1994) \\
\hline 8 & Kentucky/Fayette & Maury SiL & Tillage, fertilizer & $\begin{array}{l}\text { Blevins et al. (1977), Elliott et al. (1994), Ismail et } \\
\text { al. (1994), Six et al. (2000) }\end{array}$ \\
\hline 9 & Michigan/Barry & Kalamazoo L & Tillage, crop & Robertson et al. (2000), Six et al. (2000) \\
\hline 10 & Michigan/Clinton & Capac L & Tillage, cover crop & Pierce et al. (1994) \\
\hline 11 & Minnesota/Dakota & Waukegan SiL & Tillage, residue & Clapp et al. (2000) \\
\hline 15 & Nebraska/Lancaster & Crete SiCL & Tillage & Eghball et al. (1994) \\
\hline 16 & Ohio/Coshocton & Coshocton SiL & Tillage & Rhoton et al. (2002) \\
\hline 17 & Ohio/Wayne & Wooster SiL & Tillage, rotation & Lal et al. (1994), Dick et al. (1998), Six et al. (2000) \\
\hline 18 & Wisconsin/Grant & Rozetta SiL & Tillage & Karlen et al. (1994) \\
\hline
\end{tabular}

Notes: $\mathrm{L}=$ loam. $\mathrm{SiL}=$ silt loam. $\mathrm{SiCL}=$ silty clay loam. $\mathrm{CL}=$ clay loam.

further calibration is needed in other regions with different cropping systems.

We hypothesized that different relationships between SCI and SOC derived from field studies would be obtained from the Midwest and southeastern US regions due to differences in climate, soil type, and prevalent management systems. Our objectives were to (1) calibrate SCI scores against published SOC data derived from field experiments under various management systems in the Midwest and (2) compare the calibration curves between the Midwest and southeastern US regions.

\section{Materials and Methods}

Soil organic $\mathrm{C}$ content data $\left(\mathrm{Mg} \mathrm{C} \mathrm{ha}{ }^{-1}\right)$ from numerous field studies comparing tillage systems primarily, but also comparing crop rotation, fertilizer, and cover crop systems throughout the Midwest were obtained from original studies reported in the review of the region by Johnson et al. (2005). Index scores of SCI were predicted using Revised Universal Soil Loss Equation 2 (RUSLE2) version 1.26.6.4 for locations and management conditions that closely matched those from published reports. Published reports used to obtain SOC data and the conditions for SCI scoring are in table 1. A total of 64 observations from 18 studies were assembled from 10 states in the Midwest. Soil organic C data and SCI scores for 130 observations from 8 states in the southeastern United States were previously reported in Franzluebbers et al. (2010). In the Midwest, SOC content was regressed upon SCI scores for (1) individual locations with multiple management conditions and (2) all data with state and study as blocking criteria. The significance of slopes was tested between continuous corn (Zea mays L.) and more diverse rotations (i.e., corn-soybean [Glycine max (L.) Merr.], corn-oat [Avena sativa L.]-clover, corn-wheat [Triticum aestivum L.]-soybean). Significance of regressions was declared at $p$ $\leq$ 0.05. Summarized relationships between regions were compared with a $t$ test.

\section{Results and Discussion}

Data from the Midwest were well distributed among 10 states, with no state accounting for more than $20 \%$ of the data (table 2). Table 2 provides summary statistics for data collected within three arbitrary zones and across states. The stock of SOC was much higher in the Midwest $\left(58.8 \pm 21.4 \mathrm{Mg} \mathrm{C} \mathrm{ha}^{-1}\right.$ [26.2 $\left.\pm 9.6 \mathrm{tn} \mathrm{ac}^{-1}\right]$ ) (table 2) than in the southeastern United States $(28.5 \pm 12.2 \mathrm{Mg} \mathrm{C}$ $\mathrm{ha}^{-1}\left[12.7 \pm 5.4\right.$ tn $\left.\mathrm{ac}^{-1}\right]$ ) (Franzluebbers et al. 2010). This was partly due to the slightly greater sampling depth in the Midwest (25 $\pm 6 \mathrm{~cm}[10 \pm 2 \mathrm{in}])$ than in the southeastern United States $(20 \pm 5 \mathrm{~cm}[8 \pm 2 \mathrm{in}])$, but also due to inherent differences in soilforming factors between the two regions (Jenny 1980; Rhoton et al. 2002). Soils tested in the Midwest were Mollisols $(n=$ $10)$ and Alfisols $(n=8)$, while in the southeastern United States they were Ultisols ( $n$ $=23)$, Alfisols $(n=3)$, Inceptisols $(n=2)$, Mollisols $(n=2)$, and Vertisols $(n=1)$. Field studies also tended to be conducted for longer periods of time in the Midwest $(15 \pm 8$ years) than in the southeastern United States $(10 \pm 6$ years). Variations in characteristics among three zones in the Midwest were not large, although stock of SOC and SCI scores tended to be lowest in the south and length of investigation tended to be lowest in the north (table 2).

When pooling all pairs of SOC data and SCI scores $(n=64)$ together across 18 studies in the Midwest as a simple scatter plot, a weak $\left(r^{2}=0.03\right)$ and nonsignificant relationship $(p$ $=0.17)$ resulted. However, when data were blocked according to the 18 studies (which resulted in different absolute values of SOC due to differences in sampling depth, site history, soil texture, climatic conditions, etc.) (figure 1), a strong $\left(r^{2}=0.95\right)$ and significant relationship $(p<0.001)$ between SOC and SCI resulted in the following equation:

SOC $\left(\mathrm{Mg} \mathrm{ha}^{-1}\right)=59.4+4.52(\mathrm{SCI})$, 
Table 2

Summary statistics of soil conditioning index scores, soil organic carbon data, and associated study characteristics in three zones.

\begin{tabular}{|c|c|c|c|c|}
\hline \multirow[b]{2}{*}{ Variable } & \multicolumn{4}{|l|}{ Zone } \\
\hline & North & Middle & South & All \\
\hline Number of observations & 20 & 30 & 14 & 64 \\
\hline \multicolumn{5}{|c|}{ Soil conditioning index score } \\
\hline Mean & 0.20 & 0.02 & -0.11 & 0.05 \\
\hline sd & 0.56 & 0.58 & 0.84 & 0.64 \\
\hline Minimum & -0.9 & -1.0 & -2.0 & -2.0 \\
\hline Maximum & 1.0 & 0.9 & 0.9 & 1.0 \\
\hline \multicolumn{5}{|l|}{ Sampling depth (cm) } \\
\hline Mean & 24.1 & 24.1 & 27.1 & 24.7 \\
\hline sd & 7.0 & 4.9 & 4.7 & 5.7 \\
\hline Minimum & 14 & 15 & 20 & 14 \\
\hline Maximum & 30 & 30 & 30 & 30 \\
\hline \multicolumn{5}{|l|}{ Years of management } \\
\hline Mean & 10.7 & 17.8 & 17.0 & 15.4 \\
\hline sd & 2.4 & 9.9 & 5.6 & 8.0 \\
\hline Minimum & 6 & 6 & 11 & 6 \\
\hline Maximum & 13 & 34 & 25 & 34 \\
\hline \multicolumn{5}{|c|}{ Soil organic carbon (Mg ha ${ }^{-1}$ ) } \\
\hline Mean & 63.5 & 60.6 & 48.0 & 58.8 \\
\hline sd & 30.1 & 17.0 & 8.7 & 21.4 \\
\hline Minimum & 16 & 26 & 32 & 16 \\
\hline Maximum & 107 & 110 & 57 & 110 \\
\hline
\end{tabular}

Notes: North = Michigan, Minnesota, Wisconsin. Middle = Illinois, Indiana, lowa, Ohio.

South $=$ Kentucky, Missouri, Nebraska. sd $=$ standard deviation .

in which the slope estimate had a standard error of $1.16 \mathrm{Mg} \mathrm{ha}^{-1} \mathrm{SCI}^{-1}(0.52 \mathrm{tn}$ $\left.\mathrm{ac}^{-1} \mathrm{SCI}^{-1}\right)$. Since length of field-study investigation varied from 6 to 34 years, the slope estimate had to be further adjusted by computing the slope for each individual study and dividing by the number of years of experimentation for that study (table 3). With this calculation, the rate of SOC sequestration per unit of SCI was $0.35 \pm 0.06 \mathrm{Mg} \mathrm{C} \mathrm{ha}^{-1}$ $\mathrm{y}^{-1} \mathrm{SCI}^{-1}\left(314 \pm 57 \mathrm{lb} \mathrm{ac}^{-1} \mathrm{yr}^{-1} \mathrm{SCI}^{-1}\right)$ (mean \pm standard error of 18 observations). This calibrated slope was not significantly different $(p=0.14)$ from that derived for the southeastern United States $(0.25 \pm 0.04 \mathrm{Mg}$ $\mathrm{C} \mathrm{ha}^{-1} \mathrm{yr}^{-1} \mathrm{SCI}^{-1}\left[220 \pm 34 \mathrm{lb} \mathrm{ac}^{-1} \mathrm{yr}^{-1} \mathrm{SCI}^{-1}\right.$, which represents mean \pm standard error of 31 observations]) (Franzluebbers et al. 2010). Using equation 1, a cropping system with SCI score of -0.6 (one standard deviation lower than the mean) would be predicted to have SOC content of $56.1 \mathrm{Mg} \mathrm{ha}^{-1}$ (25.0 tn $\mathrm{ac}^{-1}$ ), while a cropping system with SCI score of +0.7 (one standard deviation greater than the mean) would be predicted to have SOC content of $62.0 \mathrm{Mg} \mathrm{ha}^{-1}\left(27.7 \mathrm{tn} \mathrm{ac}^{-1}\right)$.
Implemented over 15.4 y (mean value of dataset) (table 2), SOC sequestration rate of improved compared with conventional management would be $0.38 \mathrm{Mg} \mathrm{C} \mathrm{ha}^{-1} \mathrm{y}^{-1}(342$

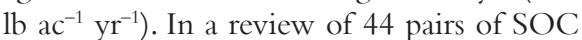
data between conventional and no-tillage in the Midwest, SOC sequestration rate was $0.40 \pm 0.09 \mathrm{Mg} \mathrm{C} \mathrm{ha}^{-1} \mathrm{y}^{-1}\left(359 \pm 82 \mathrm{lb} \mathrm{ac}^{-1}\right.$ $\mathrm{yr}^{-1}$ ) (Johnson et al. 2005); thus, the rate of $0.38 \mathrm{Mg} \mathrm{C} \mathrm{ha-} \mathrm{y}^{-1}$ with a difference of 1.3 SCI units was consistent with field studies.

When data were sorted by crop rotation, the rate of SOC sequestration under notillage compared with moldboard plowing was not different $(p=0.38)$ between studies under continuous corn $(0.31 \pm 0.14 \mathrm{Mg} \mathrm{C}$ $\mathrm{ha}^{-1} \mathrm{y}^{-1}\left[277 \pm 125 \mathrm{lb} \mathrm{ac} \mathrm{yr}^{-1}\right]$ ) (mean \pm standard error among 15 observations) and corn rotated with soybean $(0.51 \pm 0.14 \mathrm{Mg}$ $\left.\mathrm{C} \mathrm{ha}^{-1} \mathrm{y}^{-1}\left[455 \pm 125 \mathrm{lb} \mathrm{ac}^{-1} \mathrm{yr}^{-1}\right]\right)$ with $n=$ 8. The SCI scores averaged -0.6 under moldboard plowing and +0.7 under no-tillage with continuous corn and -0.5 under moldboard plowing and +0.5 under no-tillage with rotated corn. The regression of SOC on SCI was not different $(p=0.75)$ between cropping systems, in which calibration rates were $0.34 \pm 0.09 \mathrm{MgC} \mathrm{ha}^{-1} \mathrm{y}^{-1} \mathrm{SCI}^{-1}$ (304 \pm $\left.80 \mathrm{lb} \mathrm{ac}^{-1} \mathrm{yr}^{-1} \mathrm{SCI}^{-1}\right)$ under continuous corn and $0.32 \pm 0.07 \mathrm{Mg} \mathrm{C} \mathrm{ha}^{-1} \mathrm{y}^{-1} \mathrm{SCI}^{-1}(286 \pm$ $62 \mathrm{lb} \mathrm{ac}^{-1} \mathrm{yr}^{-1} \mathrm{SCI}^{-1}$ ) under rotated corn.

Since calibration slopes were not different ( $p=0.14)$ between the Midwest $(0.35 \pm 0.06$ $\mathrm{Mg} \mathrm{C} \mathrm{ha} \mathrm{y}^{-1} \mathrm{SCI}^{-1}\left[314 \pm 57 \mathrm{lb} \mathrm{ac}^{-1} \mathrm{yr}^{-1}\right.$ $\left.\left.\mathrm{SCI}^{-1}\right]\right)$ and the southeastern United States $\left(0.25 \pm 0.04 \mathrm{Mg} \mathrm{C} \mathrm{ha}^{-1} \mathrm{yr}^{-1} \mathrm{SCI}^{-1}[220 \pm\right.$ $\left.\left.34 \mathrm{lb} \mathrm{ac}^{-1} \mathrm{yr}^{-1} \mathrm{SCI}^{-1}\right]\right)$, data could be reasonably combined to yield an overall calibration of $0.29 \pm 0.03 \mathrm{Mg} \mathrm{Cha}^{-1} \mathrm{y}^{-1} \mathrm{SCI}^{-1}(255 \pm$ $\left.30 \mathrm{lb} \mathrm{ac}^{-1} \mathrm{yr}^{-1} \mathrm{SCI}^{-1}\right)(n=49)$. It should be noted that the conditions under which this calibration was established were sampling depth of $22 \pm 6 \mathrm{~cm}(9 \pm 2 \mathrm{in})$ and length of investigation of $11 \pm 7 \mathrm{y}$ (mean \pm standard deviation). Use of the calibration estimate should be kept within those conditions to be most valid.

Our analysis did not support a recommendation to have a separate calibration of SCI against SOC in the Midwest compared with the southeastern United States. Only with additional original field data indicating otherwise would a separate calibration between the two regions be necessary.

Calibration of SOC content on SCI scores from long-term field studies in other regions has been rarely investigated. We calculated a calibration slope of SOC (10 cm [4 in] depth) on SCI in 12 agroecosystems in the Southern High Plains of Texas of $0.74 \mathrm{Mg} \mathrm{C} \mathrm{ha}^{-1} \mathrm{SCI}^{-1}$ $\left(661 \mathrm{lb} \mathrm{ac}^{-1} \mathrm{SCI}^{-1}\right)$ from data reported in Zobeck et al. (2007), in which SCI was $0 \pm$ 0.9 . The relationship was equally weak $\left(r^{2}=\right.$ $0.09)$ as in the unstructured Midwest scatter plot, but it suggested that calibration slope of SOC on SCI may be lower in drier than in wetter regions. Plausible explanations for the difference in calibration slopes might be lower crop biomass production and limited amount of $\mathrm{C}$ available in plant residues to contribute to SOC sequestration. However, decomposition of available organic matter could be expected to be lower under dry than wet conditions.

In Colorado, a calibration slope of 3.38 $\mathrm{Mg} \mathrm{C} \mathrm{ha}{ }^{-1} \mathrm{SCI}^{-1}\left(1.51 \mathrm{tn} \mathrm{ac}{ }^{-1} \mathrm{SCI}^{-1}\right)$, with $r^{2}$ $=0.76$, was developed from a $7 \mathrm{y}$ evaluation (0.48 Mg C ha ${ }^{-1} \mathrm{y}^{-1} \mathrm{SCI}^{-1}\left[431 \mathrm{lb} \mathrm{ac}^{-1} \mathrm{yr}^{-1}\right.$ $\left.\mathrm{SCI}^{-1}\right]$ ) of tillage and crop rotation systems from data reported in Zobeck et al. (2008), in which SCI was $1.0 \pm 0.4$. Crop residue production was high (mean of $6.2 \mathrm{Mg} \mathrm{ha}^{-1}$ ) in this dry climate (with supplemental irriga- 


\section{Figure 1}

Relationship of soil organic carbon to soil conditioning index score from 18 studies in 10 states of the Midwest United States. Data are plotted for the 10 states for simplicity, but regression slopes were obtained for the 18 studies to yield equation 1.

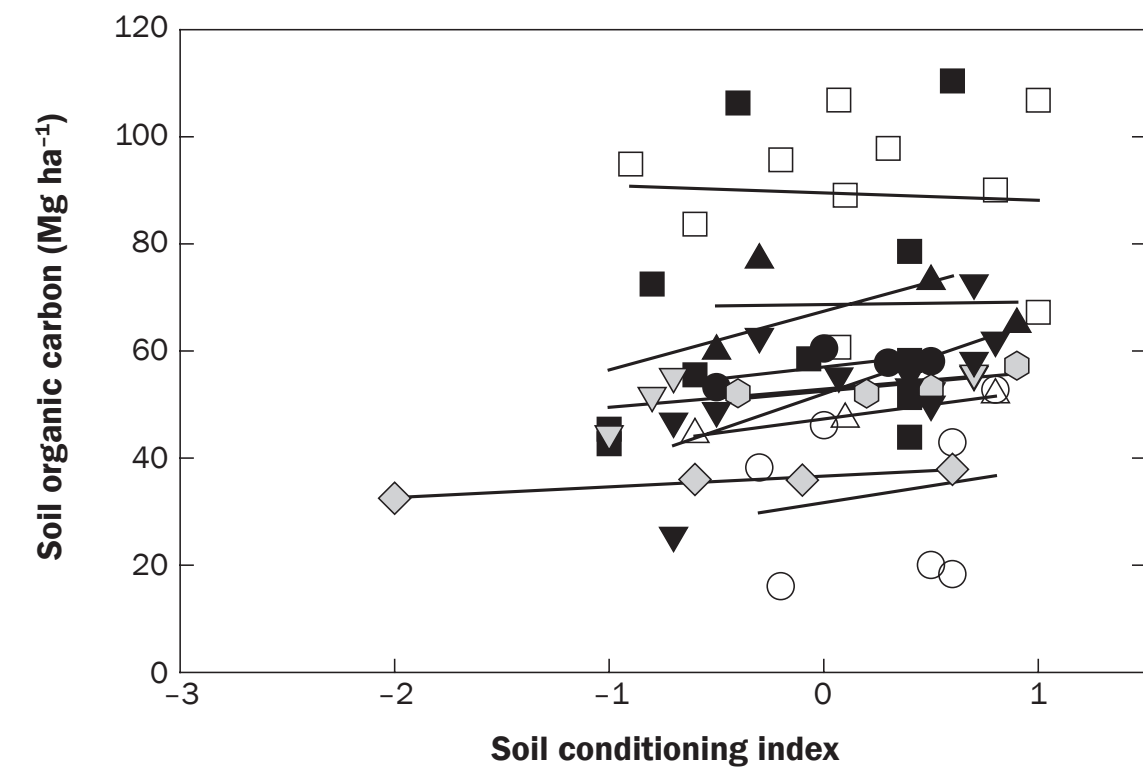

Legend
Michigan $(n=7)$
lowa $(n=4)$
Minnesota $(n=10)$
allinois $(n=11)$
Indiana $(n=3)$
Ohio $(n=11)$
$\nabla$ Kentucky $(n=6)$
$\diamond \operatorname{Missouri}(n=4)$
Nebraska $(n=4)$

tion) and this may have contributed to the high calibration slope. Since SCI scores were all $>0$ in this study, the calibration slope may have also been elevated should the relationship between SOC content and SCI score not be truly linear but instead exponential as noted by Abrahamson et al. (2007). Further research is needed to better understand the shape of calibration slopes under different soil and climatic conditions, as well as with different lengths of investigation.

Absolute SCI of a single cropping system at a specific location will not necessarily be revealing for SOC sequestration. As can be seen in the data in figure 1, significant SOC sequestration would have occurred in some cropping systems with SCI score of 0 compared to a less desirable cropping system with a score of -2 . There is a need to establish a baseline management condition so that a change in SOC can be expected. If the baseline condition were to have a highly negative SCI score, then even a minimal conservation management technique would likely improve SOC sequestration. If, however, the baseline condition were at an acceptable level, then only more rigorous conservation measures could be expected to achieve significant $\mathrm{SOC}$ sequestration in the future.

\section{Table 3}

Regression of soil organic carbon (SOC) content against the soil conditioning index (SCI) in individual studies of the Midwest United States.

\begin{tabular}{|c|c|c|c|c|c|}
\hline $\begin{array}{l}\text { Experiment } \\
\text { number }\end{array}$ & $\begin{array}{l}\text { Number of } \\
\text { observations }\end{array}$ & $\begin{array}{l}\text { Intercept } \\
\left(\mathrm{Mg} \mathrm{C} \text { ha }^{-1}\right) \\
(\text { SOC at SCl }=0)\end{array}$ & $\begin{array}{l}\text { Slope } \\
\left(\mathrm{Mg} \mathrm{C} \mathrm{ha-1} \mathrm{SCl}^{-1}\right)\end{array}$ & $\begin{array}{l}\text { Standard error } \\
\text { of slope } \\
\left(\mathrm{Mg} \mathrm{C} \mathrm{ha}^{-1} \mathrm{SCl}^{-1}\right)\end{array}$ & $\begin{array}{l}\text { Rate of SOC } \\
\text { sequestration } \\
\left(\mathrm{Mg} \mathrm{C} \mathrm{ha-1}^{-1} \mathrm{SCl}^{-1} \text { ) }\right.\end{array}$ \\
\hline 1 & 4 & 57 & 4.5 & 3.7 & 0.35 \\
\hline 3 & 2 & 50 & 4.2 & na & 0.70 \\
\hline 4 & 2 & 77 & 5.1 & na & 0.48 \\
\hline 5 & 2 & 44 & 0.9 & na & 0.08 \\
\hline 8 & 6 & 53 & 3.4 & 2.0 & 0.22 \\
\hline 9 & 4 & 43 & 8.9 & 5.6 & 0.99 \\
\hline 10 & 3 & 17 & 3.9 & 2.4 & 0.28 \\
\hline 11 & 6 & 92 & 0.8 & 4.2 & 0.06 \\
\hline 12 & 2 & 60 & 7.0 & na & 0.64 \\
\hline 17 & 9 & 55 & 8.4 & 4.8 & 0.29 \\
\hline 18 & 3 & 47 & 5.3 & 0.7 & 0.44 \\
\hline Mean/sum & 64 & 59 & 4.9 & na & $0.35 \pm 0.06$ \\
\hline
\end{tabular}

Note: na $=$ not applicable. 


\section{Summary and Conclusions}

Calibration of SOC sequestration on SCI scores for the Midwest was $0.35 \pm 0.06$ $\mathrm{Mg} \mathrm{C} \mathrm{ha}{ }^{-1} \mathrm{y}^{-1} \mathrm{SCI}^{-1}\left(314 \pm 57 \mathrm{lb} \mathrm{ac}^{-1} \mathrm{yr}^{-1}\right.$ $\left.\mathrm{SCI}^{-1}\right)$, which was not different from that of the southeastern United States, and therefore, a combined calibration was $0.29 \pm 0.03 \mathrm{Mg}$ $\mathrm{C} \mathrm{ha}{ }^{-1} \mathrm{y}^{-1} \mathrm{SCI}^{-1}\left(255 \pm 30 \mathrm{lb} \mathrm{ac}^{-1} \mathrm{yr}^{-1} \mathrm{SCI}^{-1}\right.$; mean \pm standard error of 49 slope estimates). Most of the SCI calibration scores in the Midwest were in the range of -0.6 to +0.7 . As was noted in the southeastern United States, further work is needed in the Midwest to broaden the calibration to include much higher SCI scores with highest conservation measures. Data do not support development of separate calibration curves to relate SCI to SOC changes in these two relatively moist regions, but calibration curves in drier regions have yet to be fully evaluated. The successful calibration of SOC content on SCI scores will allow SCI to become a more quantitative tool in predicting SOC content for farmers wanting to adopt conservation practices.

\section{Acknowledgements}

Financial support was provided in part by Cotton Inc. (Agr. 05-712) and USDA Agricultural Research Service GRACEnet Cross-Location Research Project.

\section{References}

Abrahamson, D.A., M.L. Norfleet, H.J. Causarano, J.R. Williams, J.N. Shaw, and A.J. Franzluebbers. 2007. Effectiveness of the soil conditioning index as a carbon management tool in the southeastern United States based on comparison with EPIC. Journal of Soil and Water Conservation 62(2):94-102.

Blevins, R.L., G.W. Thomas, and P.L. Cornelius. 1977. Influence of no-tillage and nitrogen fertilization on certain soil properties after 5 years of continuous corn. Agronomy Journal 69:383-386.

Buyanovsky, G.A., and G.H. Wagner. 1998. Carbon cycling in cultivated land and its global significance. Global Change Biology 4:131-141.

Clapp, C.E., R.R. Allmaras, M.F. Layese, D.R. Linden, and R.H. Dowdy. 2000. Soil organic carbon and ${ }^{13} \mathrm{C}$ abundance as related to tillage, crop residue, and nitrogen fertilization under continuous corn management in Minnesota. Soil and Tillage Research 55:127-142.

Cox, C.A. 2008. Beyond T: Guiding sustainable soil management. Journal of Soil and Water Conservation 63(5):162A-164A.

Dick, W.A., R.L. Blevins, W.W. Frye, S.E. Peters, D.R. Christenson, FJ. Pierce, and M.L.Vitosh. 1998. Impacts of agricultural management practices on $\mathrm{C}$ sequestration in forest-derived soils of the eastern Corn Belt. Soil and Tillage Research 47:235-244.

Duiker, S.W., and R. Lal. 1999. Crop residue and tillage effects on carbon sequestration in a Luvisol in central Ohio. Soil and Tillage Research 52:73-81.
Eghball, B., L.N. Mielke, D.L. McCallister, and J.W. Doran. 1994. Distribution of organic carbon and inorganic nitrogen in a soil under various tillage and crop sequences. Journal of Soil and Water Conservation 49(2):201-205.

Elliott, E.T., I.C. Burke, C.A. Monz, S.D. Frey, K.H. Paustian, H.P. Collins, E.A. Paul, C.V. Cole, R.L. Blevins, W.W. Frye, D.J. Lyon, A.D. Halvorson, D.R. Huggins, R.F.Turco, and M.V.Hickman. 1994. Terrestrial carbon pools: Preliminary data from the Corn Belt and Great Plains regions. In Defining Soil Quality for a Sustainable Environment, ed. J.W. Doran, D.C. Coleman, D.F. Bezdicek, and B.A. Stewart, 179-191. SSSA Special Publication 35. Madison, WI: Soil Science Society of America.

Franzluebbers,A.J.2005. Soil organic carbon sequestration and agricultural greenhouse gas emissions in the southeastern USA. Soil and Tillage Research 83:120-147.

Franzluebbers, A.J. 2010. Achieving soil organic carbon sequestration with conservation agricultural systems in the southeastern USA. Soil Science Society of America Journal 74(2):347-357.

Franzluebbers, A.J., H.J. Causarano, and M.L. Norfleet. 2010. Calibration of the soil conditioning index to soil organic carbon in the southeastern USA. Plant and Soil 338(12):223-232, doi:10.1007/s11104-010-0310-9.

Gál, A., T.J.Vyn, E. Michéli, E.J. Kladivko, and W.W. McFee. 2007. Soil carbon and nitrogen accumulation with longterm no-till versus moldboard plowing overestimated with tilled-zone sampling depths. Soil and Tillage Research 96:42-51.

Hubbs, M.D., M.L. Norfleet, and D.T. Lightle. 2002. Interpreting the soil conditioning index. In Making Conservation Tillage Conventional: Building a Future on 25 Years of Research. Proceedings of the 25th Annual Southern Conservation Tillage Conference for Sustainable Agriculture, ed. E. Van Santen, 192-196. Auburn, AL: Alabama Agricultural Experiment Station.

Ismail, I., R.L. Blevins, and W.W. Frye. 1994. Long-term no-tillage effects on soil properties and continuous corn yields. Soil Science Society of America Journal 58:193-198.

Jenny, H. 1980. The soil resource: Origin and behavior. In Ecological Studies 37. New York: Springer.

Johnson, J.M.F., D.C. Reicosky, R.R. Allmaras, T.J. Sauer, R.T. Venterea, and C.J. Dell. 2005. Greenhouse gas contributions and mitigation potential of agriculture in the central USA. Soil and Tillage Research 83:73-94.

Karlen, D.L., A. Kumar, R.S. Kanwar, C.A. Cambardella, and T.S. Colvin. 1998. Tillage system effects on 15-year carbon-based and simulated $\mathrm{N}$ budgets in a tile-drained Iowa field. Soil and Tillage Research 48:155-165.

Karlen, D.L., N.C. Wollenhaupt, D.C. Erbach, E.C. Berry, J.B. Swan, N.S. Eash, and J.L. Jordahl. 1994. Long-term tillage effects on soil quality. Soil and Tillage Research 32:313-327

Kok, H., R.I. Papendick, and K.E. Saxton. 2009. STEEP: Impact of long-term conservation farming research and education in Pacific Northwest wheatlands. Journal of Soil and Water Conservation 64(4):253-264.

Lal, R., A.A. Mahboubi, and N.R. Fausey. 1994. Long-term tillage and rotation effects on properties of a central Ohio soil. Soil Science Society of America Journal 58:517-522.
Liebig, M.A., J.A. Morgan, J.D. Reeder, B.H. Ellert, H.T. Gollany, and G.E. Schuman. 2005. Greenhouse gas contributions and mitigation potential of agricultural practices in northwestern USA and western Canada. Soil and Tillage Research 83:25-52.

Mielke, L.N., J.W. Doran, and K.A. Richards. 1986. Physical environment near the surface of plowed and no-tilled soils. Soil and Tillage Research 7:355-366.

Pierce, FJ., M.-C. Fortin, and M.J. Staton. 1994. Periodic plowing effects on soil properties in a no-till farming system. Soil Science Society of America Journal 58:1782-1787.

Rhoton, F.E., M.J. Shipitalo, and D.L. Lindbo. 2002. Runoff and soil loss from Midwestern and southeastern US silt loam soils as affected by tillage practice and soil organic matter content. Soil and Tillage Research 66:1-11.

Robertson, G.P., E.A. Paul, and R.R. Harwood. 2000. Greenhouse gases in intensive agriculture: Contributions of individual gases to the radiative forcing of the atmosphere. Science 289:1922-1925.

Six, J., K. Paustian, E.T. Elliott, and C. Combrink. 2000. Soil structure and organic matter. I. Distribution of aggregate-size classes and aggregate-associated carbon. Soil Science Society of America Journal 64:681-689.

VandenBygaart, A.J., E.G. Gregorich, and D.A. Angers. 2003. Influence of agricultural management on soil organic carbon: A compendium and assessment of Canadian studies. Canadian Journal of Soil Science 83:363-380.

VandenBygaart, A.J., X.M. Yang, B.D. Kay, and J.D. Aspinall. 2002. Variability in carbon sequestration potential in no-till landscapes of southern Ontario. Soil and Tillage Research 65:231-241.

Varvel, G.E. 1994. Rotation and nitrogen fertilization effects on changes in soil carbon and nitrogen. Agronomy Journal 86:319-325.

Venterea, R.T., J.M. Baker, M.S. Dolan, and K.A. Spokas. 2006. Carbon and nitrogen storage are greater under biennial tillage in a Minnesota corn-soybean rotation. Soil Science Society of America Journal 70:1752-1762.

Wander, M.M., M.G. Bidart, and S. Aref. 1998. Tillage impacts on depth distribution of total and particulate organic matter in three Illinois soils. Soil Science Society of America Journal 62:1704-1711.

West, T.O., and W.M. Post. 2002. Soil organic carbon sequestration rates by tillage and crop rotation: A global data analysis. Soil Science Society of America Journal 66:1930-1946.

Yang, X.-M., and M.M. Wander. 1999. Tillage effects on soil organic carbon distribution and storage in a silt loam soil in Illinois. Soil and Tillage Research 52:1-9.

Zobeck, T.M., J. Crownover, M. Dollar, R.S. Van Pelt, V. Acosta-Martinez, K. Bronson, and D.R. Upchurch. 2007. Investigation of soil conditioning index values for Southern High Plains agroecosystems. Journal of Soil and Water Conservation 62(6):433-442.

Zobeck, T.M., A.D. Halvorson, B. Wienhold, V. AcostaMartinez, and D.L. Karlen. 2008. Comparison of two soil quality indexes to evaluate cropping systems in northern Colorado. Journal of Soil and Water Conservation 63(5):329-339. 